\title{
WHICH MODEL OF ECONOMIC DEVELOPMENT IS THE BEST FOR SERBIA
}

\author{
Jugoslav Aničić, Dušan Aničić \\ University Union -Nikola Tesla, Faculty of Economics and Finance, Belgrade, \\ Republic of Serbia \\ ajugoslav@yahoo.com, anicic.dusan@yahoo.com
}

\section{Original Scientific Paper doi:10.5937/jouproman7-23588}

\begin{abstract}
The neoliberal model of economic development implemented by the most developed countries of the West in the recent years has caused great financial world crisis; it also led to a slowdown in the world economic growth as well as huge social inequality in the world. On the other hand, certain countries, with China as a distinct representative, have been developing their economies independently, according to the tradition and their own experience, where the government institutions, in addition to the market, have an important role in the issues of economic development. Transition countries, Serbia among them, have mainly accepted the neoliberal model of development, with an even greater lag behind the world most developed countries as a result. This paper indicates the need for the implementation of individual models of economic development, based on the specific development potentials and adjusted to the countries' conditions. It is better to introduce social and economic reforms gradually, in order to achieve rapid and sustainable economic development, according to the appropriate opportunities, rather than follow the trends blindly and implement reforms at any cost.
\end{abstract}

Keywords: economic development, Serbia, China, EU, USA

\section{Introduction}

During the last decades, the most developed countries such as the USA, as well as the EU and others, have implemented the development model based on "The Washington Consensus", supported by the leading world financial institutions - the IMF and the World Bank. This concept is based on the neoliberal capitalism with the dominant role of the market and the exclusion of the state from the economic development issues. However, the great economic crisis from 2008 has shattered the illusion about the market as the most successful type of economic development. It also proved that human economic activity has its roots in both social and political environment, and it is always a means to achieve social goals. People should manage markets, not vice versa because such a model resulted in a universal crisis of the contemporary society at general as well as the national level.

On the other hand, the economic development achieved by China in the previous decades captures a lot of attention of the economists around the world, bearing in mind particularly that this country has implemented a development model based on the dominant government influence on economic trends, therefore completely opposite to the neoliberal model dominant in the USA, the EU and other Western economies. China has chosen the concept of economic development suitable for the conditions in their country, based on the tradition and personal experience, excluding the cycle of economic trends typical for the Western countries. 
Therefore China has become the second world economy, the largest exporter and the country with the highest foreign exchange reserves in the world. They have achieved an impressive stage in economic development without creating huge social differences so typical for the developed countries in the West.

A growth model implemented in the transition period in Serbia is based on the services and individual consumption sector growth, whereby the income from company privatization was spent without production facilities being restored. There was a large amount of borrowing from the banks by the state and citizens, as well as unnecessary large exports enabled by the policy of overpriced dinar as currency. The result of such economic policies made Serbia a country with a very low GDP per capita, high unemployment rate, low standard of living and huge young educated personnel outflow. The situation demands a new economic policy, adjusted to the specific conditions as well as development liabilities. The cooperation with China through 'One Belt, One Way' initiative, the success of Chinese investments into Zelezara Smederevo steel plant as well as other joint projects indicate that none of the economic development models should be strictly followed but individual models should be created, based on its natural and social assumptions.

\section{The economic development of Serbia in the transition period}

At the end of the twentieth century, the globalization process changed the world market structure and made way for the creation of conditions for monopoly and oligopoly relations in the world economy. Global companies define production, trade and investment flow in the world thus managing the world economy. Only large companies can make profit in most of the activities while the small ones do business depending on the cooperation with large global business groups. The most important changes in the international business environment are the reduction in market obstacles, fast market movements, constant competitive pressure, large separations or mergers, global capital market approach (Danielle et al, 2006). New trends in globalized market demand successful company positioning in the world market as well as adaptability to local market challenges (Colin et al, 1992).

The global financial crisis of 2008 imposed the issue of the globalization role in modern world trends, and the point is whether the process enables the economic development of all the countries or it only leads to the increase in already existing inequalities in the development of certain countries. The financial crisis affected a number of countries, the EU members among them being Greece, Spain, Italy, Portugal, additionally aggravating the issue of the relations between the economically developed part of the world, as well as increasing of indebtedness and poverty in the economic outskirts (Aničić et al 2019). The tendency of company consolidation as well as monopoly and oligopoly structure creation still continues because large multinational companies solve potential competition problems through the purchase of smaller companies, improving their financial strength through the increase of market share and user numbers. 
The economic development of the transition countries was based on the IMF and the World Bank principles as the main advocates of the neoliberal economic concept. From 1990 to 2000, most of the transition countries showed a negative growth rate (EBRD, 2010). In addition to the recession, unemployment growth and population social growth stratification were also distinct. After the year 2000 until the global economic crisis, the transition countries had high economic growth rates (5.7\% on average) with the optimistic evaluations of further growth (Lissowska, 2014).

Transition countries took a stand about the necessary transition from market economy system at the beginning of the 1990s, and they started the appropriate reforms in that direction. The switch to market economy was supported by the political decision about abandoning the socialist system. With the transition to market system of economy, the transition countries also accepted new market rules which implied privatization and economic activities deregulation, financial and foreign trade flow liberalization, state role reduction, restructuring of the economy and institutional system reorganization (Sachs, 1994).

However, the financial crisis reduced consumption and investments which led to a slow-down in economic growth, loss of jobs and decrease in earnings. Most of the countries encountered the problem of budget deficit and means of its financing. Due to the emerging macroeconomic instability, the countries made fitting arrangements with the IMF, increasing their foreign debt in that way. According to Stiglitz (2004), world financial institutions had no solution for development problems of the developing countries so it was necessary to offer new solutions providing the economic growth along with the state and market cooperation.

The economy of the Republic of Serbia achieved very modest results in the transition period : low GDP per capita, high unemployment rate, low level of average earnings, escalation of regional disparities in development etc. These results are the consequences of accepting the neoliberal development concept with privatization, liberalization deregulation, with reduced role of the state in economic trends as axioms. The results achieved in the Serbian economy in the transition period indicate a large number of weaknesses as well as large lags behind the developed world economies. GDP growth rates are far below the expected ones, so GDP per capita in Serbia today, almost three decades since the beginning of the transition, is lower than in 1989.

Serbia has unfavorable economic structure because it neglected the real sector of economic development, especially industry. A small part of the economy is transformed into a new, modern economy which employs a small share of the population. Inequality and poverty rates are among the highest in Europe, and the population number is constantly reducing due to the departure of working age population to the developed countries. Moreover, certain undeveloped regions and rural areas are becoming empty because of people leaving for large city centres, especially the young and educated population. Such tendencies endanger the concept of sustainable development of the country that should be based on the steady economic growth, environment protection as well as social and human rights improvement. 
Table 1: Basic macroeconomic indicators in the transition period

\begin{tabular}{|l|l|l|l|l|l|l|l|l|l|l|l|}
\hline & 2008 & 2009 & 2010 & 2011 & 2012 & 2013 & 2014 & 2015 & 2016 & 2017 & 2018 \\
\hline GDP real growth (in \%) & 5.7 & -2.7 & 0.7 & 2.0 & -0.7 & 2.9 & -1.6 & 1.8 & 3.3 & 2.0 & 4.3 \\
\hline $\begin{array}{l}\text { Balance of payments current } \\
\text { account (in GDP \%) }\end{array}$ & -20.0 & -6.3 & -6.5 & -10.3 & -10.9 & -5.8 & -5.6 & -3.5 & -2.9 & -5.2 & -5.2 \\
\hline $\begin{array}{l}\text { Unemployment according to } \\
\text { survey (\%) }\end{array}$ & 13.6 & 16.1 & 19.2 & 23.0 & 23.9 & 22.1 & 19.2 & 17.7 & 15.3 & 13.5 & 12.7 \\
\hline $\begin{array}{l}\text { Public debt of the RS (central } \\
\text { level, GDP \%) }\end{array}$ & 26.8 & 30.9 & 39.5 & 42.8 & 52.9 & 56.0 & 66.2 & 70.0 & 67.8 & 57.9 & 53.8 \\
\hline
\end{tabular}

The source: National Bank of Serbia

The data in table 1 show very low GDP growth rates, even negative in certain years. With these GDP growth rates, Serbia cannot achieave the development level of the Central and Eastern European countries, as the goal to be pursued in as short term as possible. Unemployment has been reduced, but we should have in mind that a large number of young people are leaving for work to other countries, as well as a low quality of a large number of jobs in the country. Current balance of payment has been negative thoroughout the entire period, and a positive circumstance is public debt reduction since 2015 when it reached high 70 percent.

Government institutions in charge of economic development are still in the reform stage as well as adjustments to modern tendencies in the world. The institutional reform began with rapid destruction of the institutions from the previous political and economic system, but the formation of new market institutions is slow, inefficient and partial. It is beyond doubt that there are no sustainable high economic growth rates without the development of stable institutions and vice versa, it is not possible to create stable institutions without high economic growth rates (Jakopin, 2018). There are also numerous undefined jurisdictions between central and local institutions of economic development because local authorities need more autonomy in order to implement development activities in their regions.

The connection between the institutional underdevelopment and extremely present corruption primarily affects the transition countries through 'brain drain' and human capital quality. It is determined empirically that high levels of corruption affect the level of qualified workforce emigration much more than unqualified workforce migration (Dimant et al, 2013). Higher levels of corruption are connected to lower levels of education, healthcare, social and economic development, thus affecting the reduction in human capital levels.

The rule of law in economic relations is at a low level, entrepreneurship development has not gained necessary dimensions nor has it been supported in the manner appropriate by the competent authorities. Agriculture sector could play a more important role in economic development according to its potentials, primarily in higher exports and foreign trade deficit reduction. Positive macroeconomic results in the post-crisis period are fiscal consolidation and inflation reduction below 3 percent. 
Foreign direct investments had no significant contribution to economic growth since they were invested in the sectors that created low additional value due to the unfavorable economic structure, and therefore they were less efficient. The policy of foreign investments stimulation and attraction was led during the transition period, at the expense of local investors. Regardless of the numerous foreign direct investments positive effects, it is certainly not a good idea that the development is based on foreign investments alone since it increases foreign property value in the long term, affecting the profit outflow as well as capital withdrawal in case of crisis.

The characteristics of the transition period in Serbia are also unfavorable conditions for lending to the economy (and citizens) by the banking sector, resulting in the loan beneficiaries paying some of the highest interests and fees in Europe. These conditions led to capital overflow from the real to the banking sector, often with the NBS as a silent observer in the process. Interest rate reduction in the largest world central banks such as FED, European Central Bank, the Bank of Japan reached Serbia with a great delay, especially reflected in the NBS reference rate flows concerning the rates of the aforementioned banks (Aničić, et al, 2019).

According to the World Economic Forum report for 2018, Serbia was in the 65th place in the list of global competition index, among 140 world countries observed (the previous year it was in the 70th place, thus the improvement in ranking by 5 places). According to Arsić (2016), after two and a half decades of the transition, Serbia is in a small group of Central and Eastern Europe countries (CEE) still not having achieved the development level from the pretransition period, while CEE countries increased GDP for almost $60 \%$ in the same period. The result of the divergent development in the above mentioned period was that the CEE countries were on average $85 \%$ more developed than Serbia in 2015, although Serbia was at the same level with this group of countries in 1989.

Table 2: Serbia, the CEE countries and the region: investments, import and export share in GDP, the average for $2014-2017$

\begin{tabular}{|l|l|l|l|}
\hline & Investments & Import & Export \\
\hline \multicolumn{3}{|c|}{ GDP share } \\
\hline Serbia & 17.7 & 48.1 & 57.4 \\
\hline CEE countries (weighted average) & 21.2 & 60.9 & 58.6 \\
\hline $\begin{array}{l}\text { The countries in the region } \\
\text { (weighted average) }\end{array}$ & 22.0 & 56.1 & 56.5 \\
\hline
\end{tabular}

The source: Eurostat, 2018 
The results in table 2 show that the investment and export share in GDP is considerably lower than the average in the CEE countries as well as in the countries in the region. There are opportunities for investment and export increase, some of them are as follows: public investments by the state with a positive effect on the growth in other industries, public companies reform, corruption reduction, state administration efficiency increase, etc.

Growth model implemented in Serbia in the transition period was based on individual consumption and services growth, with privatization income spending, accelerated government and population borrowing from the banks as well as cheap imports enabled by the overpriced dinar policy; this model proved to be wrong. The basic incentive for sustainable growth should be investments, used to build new production facilities (Pejanović, 2017).

The above mentioned facts indicate that there was no adequate economy development strategy which resulted in low-level macroeconomic indicators. Therefore, there is a practical danger for the current economic policy to stabilize the country at the low GDP level with high unemployment, low labor cost and poor working conditions for a large share of the employed people. With no national banks directed towards development financing, no independent monetary policy, no credit control or loans directed to local companies based on transparent strategy and priorities, there are no efficient investments or independent development.

\section{China as an example of independent development}

The global financial crisis of 2008 shattered the illusion about a market experienced as a fetish and absolute, as well as the one about market self-regulation. Stiglic (2014) reminds us that the economic activities of a man are rooted in both social and political environment. It is always a means to achieve social goals. He emphasizes that 'man should manage markets, not the other way round'. Otherwise, there is a danger of market fundamentalism at the expense of men, society and the environment. Such a model resulted in a general crisis affecting modern society at the global as well as the national level. The process of welfare state destruction begins with neoliberalism. It is particularly the case in weak European concept of social model, seriously threatened by the global financial crisis, rigorous savings and cost-cutting imposed as a measure in the EU by Germany and the IMF (Pikkety, 2015).

On the other hand, the economic development achieved by China in the recent decades has attracted special attention of the economists around the world, especially given the fact that this country implements a model based on the dominant impact of the state on the economic trends; therefore, it is completely opposite to the neoliberal model dominant in the USA, EU and other Western economies.

How is it possible that China has achieved such success in the economic results, with 40 years of uninterrupted high-rated growth, no recession or stagnation frequent in the Western countries' economies? 
First and foremost, China has chosen a concept of economic development suitable for the Chinese conditions, based on tradition and their own experience, excluding cyclic trends in the economy so characteristic for the Western countries. China is an example of the importance of tradition and experience in sustainable development and investment expansion achievement around the world.

China started the policy of reforms and opening up at the end of 1978. The program of economic reforms was named Socialism with the Chinese characteristics, and it anticipated the transition to the socialist market economy, opening the country to the world and foreign trade, foreign investments and modern technologies. The reformists' goal was to accelerate their country's economic development through the implementation of the market principles typical for the capitalist economies, and their combination with the socialist central economy (Janković, 2017).

The emphasis of the reforms was on the socalled four modernizations - in agriculture, industry, defense of the country, science and technology. This opening to the world made it possible for China to achieve enormous growth and development. The role of ideology was reduced in the course of economy management, the concept of the social development model was named socialism with the Chinese characteristics, with a strongly expressed pragmatism (and the maxim 'it is not important whether the cat is black or white, it is important it can catch a mouse'). Deng Xiaoping, the leader of the reforms, also launched the concept 'one country - two systems' implying the coexistence of different economies in socialism and capitalism.
In its economic development, China relies on its own planning which has given excellent results, unlike Serbia that virtually abandoned the planning concept. They dealt with the internal disagreements on the development issues, and the strategic decision making was relocated from the government of China because there was a separate body dealing with the state companies as well as the strategy of economic development. This orientation succeeded in, among other things, the rise of 800 million people above the poverty rate.

China has been conducting an independent monetary policy where the National Bank is devoted to the economic growth and higher employment, but it is not independent of the government of China as is the case in a lot of countries ,bragging' about the Central Bank independence, although they have poor economic results. The banking sector is $90 \%$ state-owned, and that is totally opposite of Serbia where the banks are more than $90 \%$ majority-owned by private, mostly foreign owners. Yuan exchange rate policy is in the function of export increase. Developed countries of the West are trying to impose their development concepts on other countries, while China operates on a win-win system, without the aggressive imposition, with the aim of the economic cooperation and trade in the mutual interest.

The educational system has been developing increasingly, with a large number of personnel educated in the USA, Great Britain and the EU countries, but they return to their countries helping in their development. Due to the enormous numbers of citizens, there is a potential for the education of a large number of young personnel. 
Unlike China, the USA educates its elite at very high prices that a small number of people can finance, therefore decreasing the scientific potential in the long run. Hence the breakthrough of the Chinese companies in the field of information technologies as well as practical possibility to take over the supremacy over the Silicon Valley worldwide.

A motto has been widespread in China that it is good to be wealthy but in a legal manner. Corruption and commercial theft are punished severely, even with capital punishment. Rich people cannot take capital out of the country as they wish, the consumption of luxury goods is allowed, but only in the country. On the other hand, there are numerous examples of uncontrolled withdrawal of capital acquired in questionable ways in some countries, Serbia included.

Nowadays, China is the second economy in the world, the largest exporter with the biggest foreign exchange reserves. China is a country of complexities and contradictions which has become an open market economy after decades of reforms; led by the Communist party from the absolute poverty to medium-developed country and the initiator of world economy. It is also the most successful story of the economic transition. Chinese reformists approached the reform without dogmas, understanding transitions as an inevitable and long process of distortion correction in its economy as well as opening to the world.

The international relations after the Second World War were shaped by the USA USSR relations and the USA adjusted the set of global rules to its needs in the last twenty years. However, it is obvious that the unipolar world no longer exists nowadays. It is particularly typical that the Chinese show a very high level of trust for their government and they take a place at the top of Edelman's Trust index. The explanation of such an impressive growth lies, among other things, in good government institution functioning, which represents a connection between the Communist party loyalty and public services professionalism. The manner of personnel management and the political system in China were favorable for fierce competition between political and developing ideas, leading to such highefficiency levels.

Chinese policies abroad are strategically designed in the medium-long and long run. State-owned companies have direct support in big investment projects, while the private ones partly have direct and partly indirect support within state agreements. Although natural resources play an important part in foreign investments, their flows move towards higher technology stages and developed industrial countries (Antevski, Filipović, 2014). Chinese investments sector and geography distribution determinants abroad confirm earlier experiences in the international capital flow.

From the geographical aspect, the Chinese investments show a great dispersion, but they are mainly placed into the developing countries. China invests mostly into the energy and infrastructure projects in these countries. In the developed countries, China considers market size as a key factor, and the Chinese investors' goal is to carry out strategic take-over and positioning in the developed countries markets. 
China supports its investors in their investments into the underdeveloped and developing countries, approving them a preferential status, while the reciprocity principle is applied in case of the developed countries. Commerce is the first incentive of investment capital, and the investments into infrastructural projects additionally encourage trade growth (Filipović, Petrović, 2015)

The economic rise of China has its appropriate foundation in corporative structure and the endeavor to increase production quality as well as to be competitive with the leading Western manufacturers. Large steps have been taken in product branding. Leading Chinese companies have exceeded the national borders and they have become the leaders in the region as well as the world with its industries such as Lenovo in computing, ICBC in banking (the largest commercial bank in the world), Alibaba on the Internet, Cherry and Geely in car industry, ZTE and Huawei in telecommunications, and others. Chinese products have developed from once low quality and cheap substitutes into symbols of high quality which goes with a distinctive brand.

Success and sustainability of the Chinese economic development model are beginning to be observed as a challenge for the so far prevailing ,Washington Consensus'. It seems that such a development of China has started to bother the most developed Western countries. There is a trade war on between the USA and China, and the EU is trying to limit foreign investments in its territory. Thus the European Parliament adopted the rules on the foreign direct investments screening within the European Union in February 2019. It was explained by the necessity to protect strategic companies, infrastructure 54 and technology from potential security risks represented by foreign investors.

The strategy „Made in China 2015“ predicts ten priority sectors development, from high technologies, pharmaceutical industry, marine equipment to robotics, in addition to the existing industry upgrade and domestic market development. The strategic purchase of the companies from the above-mentioned sectors caused fear from technology transfers to China, and therefore the limits set by the EU are easy to understand because short-term, financial benefit would cause a long-term decline of the EU countries position in the world market. The advantages of China on the national level, such as high level of savings, numerous and well-trained workforce, great possibilities of further urbanization, are the foundations to maintain rapid economic development in the future.

Serbia is one of the first countries that has expressed the support for Belt and Road Initiative, and it has taken part in the construction of the project within this initiative. The initiative is linked to world development, advocating mutual progress in peacetime conditions. Also, this initiative helps the improvement of mutual relations of the countries in the environment and enables them to develop together. Large Chinese investments that have proven to be extremely good for the recipient countries also contribute to the confidence of these countries towards the Chinese economy and its government. One of the good examples in Serbia is Zelezara Smederevo steel plant that is operating successfully at the moment, although it has been managed by the Western companies and professional management in the previous period, among others, hired by the Serbian government, they only achieved negative business results. 


\section{Conclusion}

Serbian economy is lingering behind the economies of the EU and the region, especially following the 2008 financial crisis. These tendencies demand the change in the economic policies of the country in order to create the assumptions for longterm sustainable development and competition increase in regional as well as world limits. There is a practical danger for the current economic policy to stabilize the country at low GDP level, high unemployment rate, low labor cost, the sale of the most important natural resources and vital part of the economy. All of this is the result of the lack of the appropriate economic development strategy in the transition period because the economic policy creators have implemented the neoliberal development concept at fullscale, modeled after the developed Western economies.

The economic results achieved by China in about the last forty years indicate that every country should strive for its individual development model based on its tradition, experience and economic potentials available. Therefore, development models that had good results in some other countries should not be implemented at any cost, especially in the short term. The 2008 world financial crisis convinced the world economy that the market concept with no interference of the state is not almighty, on the contrary, it can lead to the enormous adverse effects on the national economies of a large number of countries implementing it. Economic policymakers in Serbia should learn from the example of China, regardless of the many differences between the two economic systems, country size, etc. It is indisputable that it is better to gradually implement social and economic reforms to the best of our abilities than to follow the trends blindly and implement reforms at all costs.

\section{References}

Antevski, M., Filipović, S., (2014) Inostrane investicione aktivnosti kineskih kompanija, Medjunarodni problem 66 (3-4), p 231-248.

Arsić, M., (2016) Dugoročne posledice ekonomskog sloma privrede Srbije tokom 90-tih godina, Kvartalni monitor, br. 44, Beograd

Aničić, J., Aničić, D., Kvrgić, G., (2019) Sustainable growth and regional competitiveness of Serbian economy, Ekonomika, Vol.65, No 2, p 6574, ISSN 0350-137X, EISSN 2334-9190, UDK 338 (497.1)

Colin, C. T., (1992), Creating the Global Company: Successful Internationalization, McGraw-Hill, New York

Danielle, M, W., Thomas, W., Joerg, S., (2006) Doing Business Internationally; The Guide to CrossCultural Success, McGraw-Hill, New York

Filipović, S., Petrović, P., (2015) Pozicioniranje privrede u globalnom ekonomskom okruženju, Ekonomski institut, Beograd, p 122-123

Dimant, E., Krieger, T., Meierrieks, D., (2013) The effect of coruption on migration 1985-2000. Applied Economics Letters, 20(13), 1270-1274, doi.org/10.1080/13504851.2013.806776

EBRD, (2010), Transition report, Recovery and Reform

Janković, A., (2017) Chinas economic development : connectivity, Shinese Way, Silk Road Connectivity Research Center, Belgrade, p 40-41.

Jakopin, E., (2018), Privredni rast i institucionalna tranzicija Republike Srbije, Ekonomski horizonti, Maj-Avgust 2018, Volumen 20, Sveska 2, str. 95108 ,

Lissowska, M., (2014) Welfare against Growth Gains in Post-Transition Countries. What are the Conseguences for Stability? http://dx.doi.org/10.5018/economicejournal.ja.2014-13

Narodna banka Srbije, (2019) Osnovni makroekonomski pokazatelji, Beograd

Pejanović, R., (2017) Razvojni problemi privrede i društva, Akademska knjiga, Novi Sad, str. 118 
(JPMNT) Journal of Process Management - New Technologies, International

Vol. 7, No 4, 2019.

Piketi, T., (2015) Kapital u 21. veku, Akademska knjiga, Novi Sad

Sacsh, J., (1994) Shock Therapy in Poland: Perspectives of Five Years, Tanner lectures, University of Utah

Stiglitc, J., E., (2004) The Post-Washington Consensus, The Initiative for Policy Dialogue
Stiglitc, J., E., (2014) Slobodan pad, Akademska knjiga, Novi Sad

WEF., (2018). Global Competitiveness Report. Geneva: World Economic Forum

www.:ec. europa.eu/eurostat, pristup sajtu 15.07.2019. godine 